\title{
PEMBELAJARAN JARAK JAUH BERBASIS MOBILE E-LEARNING DI SEKOLAH DASAR
}

\author{
Lailiya Luthfiyah Choir ${ }^{1}$, Jihan Alhanin Choir ${ }^{2}$ \\ ${ }^{1}$ UIN Sayyid Ali Rahmatullah, ${ }^{2}$ STIBADA Masjid Agung Sunan Ampel \\ 'e-mail: lailiyaluthfiyahchoir@gmail.com, ${ }^{2}$ jihan.alhanin@stibada.ac.id
}

\begin{abstract}
Distance learning is carried out by various educational institutions to keep up the teaching process in the covid-19 pandemic conditions that make it impossible to carry out the usual face-to-face learning. With the elimination of face-to-face learning, teachers and students must again design the teaching-learning process that all students can access. The purpose of this research is to describe the preparation, implementation, and constraints of distance learning factors based on mobile elearning in MI Hidayatul Mubtadiin. The research method used in this research is a descriptive qualitative method. The results of this research are for educators to do distances learning planning and the tools needed, and implementation of online learning is done by utilizing their personalized mobile e-learning capabilities and tailored to the curriculum used. Learning barrier factors include a lack of student understanding, a lack of motivation for students' home learning, a parent's inconstant companion to child learning, the capacity of inadequate communication tools, a decline in parents' economic incomes during the pandemic, and an unstable Internet network.
\end{abstract}

\begin{abstract}
ABSTRAK
Pembelajaran jarak jauh dilaksanakan oleh berbagai lembaga pendidikan sebagai usaha untuk tetap melaksanakan proses belajar mengajar dalam kondisi pandemi COVID-19 yang tidak memungkinkan untuk melaksanakan pembelajaran tatap muka seperti biasanya. Dengan ditiadakannya pembelajaran tatap muka, guru dan siswa harus kembali merancang proses belajar mengajar yang dapat diakses seluruh siswa. Tujuan penelitian ini adalah untuk mendeskripsikan persiapan, pelaksanaan, dan faktor penghambat pembelajaran jarak jauh berbasis mobile e-learning di MI Hidayatul Mubtadiin. Metode penelitian yang digunakan dalam penelitian ini adalah metode kualitatif deskriptif. Hasil penelitian ini adalah pendidik melakukan perencanaan pembelajaran jarak jauh beserta perangkat yang dibutuhkan, serta pelaksanaan pembelajaran daring dilakukan dengan memanfaatkan mobile e-learning yang telah disosialisasikan kepada guru dan orang tua dan disesuaikan dengan kurikulum yang digunakan. Faktor penghambat pembelajaran berupa kurangnya pemahaman siswa, kurangnya motivasi belajar siswa di rumah, keadaan orang tua yang tidak bisa selalu mendampingi belajar anak, kapasitas dari alat komunikasi yang tidak memadai, penurunan pendapatan ekonomi orang tua di masa pandemi, dan jaringan internet yang tidak stabil.
\end{abstract}

Kata Kunci: Pembelajaran Jarak Jauh, Mobile E-learning 


\section{PENDAHULUAN}

Pandemi COVID-19 yang terjadi di tahun 2020 memberikan dampak dalam dunia pendidikan, dari pendidikan anak usia dini sampai perguruan tinggi. Untuk menekan penyebaran COVID-19, pemerintah menghimbau seluruh warga negara Indonesia untuk tetap berada di rumah dalam melakukan kegiatan sehari-hari seperti bekerja, belajar, dan sebagainya. Peraturan ini dilaksanakan sesuai dengan Surat Edaran Mendikbud No. 4 Tahun 2020 tentang Penerapan Kebijakan Pembelajaran dalam Masa Darurat Penyebaran COVID19 bahwa Lembaga Pendidikan harus menerapkan physical distancing dengan melaksanakan pendidikan secara daring ataupun pendidikan jarak jauh. Meskipun situasi mengharuskan siswa berada di rumah, maka pendidik harus memastikan bahwa kegiatan belajar mengajar tetap berjalan dengan baik. Pendidik dituntut untuk merancang media pembelajaran sebagai inovasi dengan memanfaatkan media online. Adanya pandemi ini memacu dunia pendidikan untuk memanfaatkan lebih banyak informasi teknologi dalam kegiatan pembelajarannya. Sistem pembelajaran yang dilakukan saat ini memanfaatkan teknologi informasi. Oleh karena itu, dapat dikatakan bahwa dunia pendidikan tidak dapat terpisah dari perkembangan komunikasi teknologi. ${ }^{1}$

Pendidikan berbasis teknologi informasi dan komunikasi yang disebut dengan $e$ learning ini sudah digagas menjadi inovasi pembelajaran yang dapat meningkatkan peran siswa dalam proses pembelajaran di era pandemi. E-learning dalam sejarah Indonesia sebenarnya sudah ada sejak tahun 1990 dikenal dengan Era Computer Based Training (CBT) yaitu pembelajaran yang dilakukan dengan menggunakan bantuan PC standlone atau komputer. ${ }^{2}$ E-learning secara resmi merupakan pendidikan dengan kurikulum, silabus, mata pelajaran serta uji yang sudah diatur serta disusun bersumber pada agenda yang sudah disepakati pihak-pihak yang bersangkutan. Dengan sistem konten E-learning ini siswa dapat mengikuti kelas serta ikut ujian dari tempat bekerja atau tempat tinggalnya. ${ }^{3}$ Lahirnya berbagai produk hasil perkembangan teknologi memungkinkan pengembangan fitur $E$ learning seperti perangkat teknologi informasi genggam dan bergerak yang disebut dengan mobile. Mobile banyak diminati masyarakat karena bentuknya yang simpel dan mudah dibawa. Sebagian keahlian yang wajib disediakan oleh fitur media pendidikan mobile merupakan terdapatnya keahlian untuk terkoneksi ke perlengkapan lain, keahlian menyajikan

\footnotetext{
${ }^{1}$ Robert Connor Chick et al., "Using Technology to Maintain the Education of Residents During the COVID-19 Pandemic,” Journal of Surgical Education, 2020, https://doi.org/10.1016/j.jsurg.2020.03.018.

${ }^{2}$ Lidia Simanihuruk dkk, E-Learning: Implementasi, Strategi, Dan Inovasinya (Medan: Yayasan Kita Menulis, 2019).

${ }^{3}$ Muhammad Imanuddin, Membuat Kelas Online Berbasis Android Dengan Google Classroom (Yogyakarta: Garudhawaca, 2018).
} 
data pendidikan serta keahlian untuk merealisasikan komunikasi bilateral antara pendidik dan peserta didik. ${ }^{4}$

Pembelajaran jarak jauh adalah pendekatan pengajaran di mana siswa tidak selalu hadir secara fisik di sekolah. Secara tradisional, biasanya melibatkan pembelajaran korespondensi dimana siswa berkorespondensi dengan sekolah melalui pos. Pembelajaran jarak jauh menggunakan media dalam banyak bentuk dan pada tingkat yang berbeda. Media yang digunakan dapat berupa pos, faksimile, radio, televisi, siaran satelit, kaset video, telekonferensi, surat elektronik, chatroom, bulletin, CDROM, internet dan World Wide Web. ${ }^{5}$ Namun, seiring dengan berkembangnya teknologi yang memungkinkan pembelajaran ini maka semua institusi yang menggunakan pendekatan jarak jauh kini melibatkan pendidikan online di dalam kurikulumnya. ${ }^{6}$ Internet menjadi dominan dalam media pembelajaran jarak jauh, hal ini dapat dibuktikan dengan fokus pembelajaran jarak jauh yang sekarang telah bergeser ke arah teknologi berbasis jaringan (secara umum) dan pengiriman yang berbasis internet (lebih spesifik). ${ }^{7}$

Media pembelajaran mobile banyak digunakan dalam berbagai mata pelajaran sebagaimana penelitian yang dilakukan Siti Shofiyah pada tahun 2016 untuk mengetahui pengaruh penggunaan android dan e-learning terhadap hasil belajar siswa mata pelajaran IPS, hasil penelitian menunjukkan bahwa penggunaan android dapat meningkatkan hasil belajar siswa. Hasil penelitian Rika Santica Devi pada tahun 2019 untuk mengetahui pengaruh media mobile learning berbasis android terhadap motivasi dan hasil belajar biologi menunjukkan bahwa media tersebut berpengaruh positif sehingga mampu meningkatkan motivasi dan hasil belajar siswa dalam mata pelajaran biologi. Sejalan dengan penelitian yang dilakukan oleh Misroh Anik yaitu untuk mengetahui pengaruh penggunaan smartphoneemind mapping pada kemampuan membaca dan motivasi belajar siswa dengan hasil penelitian menunjukkan bahwa penggunaan media tersebut tidak dapat membantu siswa dalam nilai kemampuan membaca yang lebih baik tetapi dapat meningkatkan motivasi belajar siswa. Dari berbagai penelitian terdahulu yang sudah dipaparkan menunjukkan bahwa penggunaan media pembelajaran mobile sudah banyak digunakan untuk membantu proses belajar siswa. Begitu juga dengan MI hidayatul Mubtadiin yang melaksanakan pembelajaran jarak jauh berbasis mobile e-learning. Pendidik memanfaatkan berbagai fitur yang ada didalam smartphone

\footnotetext{
${ }^{4}$ Yohan Adi Setiawan, Belajar Android Menyenangkan (Surabaya: Pustaka Media Guru, 2017).

${ }^{5}$ Richard Discenza dkk, The Design and Management of Effective Distance Learning Programs (London: IRM Press, 2002).

${ }^{6}$ Amri Tanduklangi dan Carlina Amri, Manajemen Sumber Daya Pembelajaran Bahasa Berbantuan Komputer (Yogyakarta: Deepublish, 2019).

${ }^{7}$ Patricia Rogers dkk, Encyclopedia of Distance Learning, 2nd ed. (New York: Information Science Reference, 2009).
} 
untuk melaksanakan pembelajaran seperti whatsapp, google class room, zoom, youtube, dan lain sebagainya.

Smartphone dipilih karena sebagian besar wali murid MI Hidayatul Mubtadiin memilikinya dan memberikan aplikasi yang mudah digunakan sehingga tidak ada hambatan untuk tersampaikannya materi pembelajaran. Pembelajaran jarak jauh menuntut guru dan siswa bekerjasama baik dalam segi metode maupun alat yang digunakan agar pembelajaran tetap kondusif di tengah pandemi. Memiliki alat minimal berupa smartphone yang terhubung dengan jaringan internet menjadi sebuah keharusan untuk mengikuti pembelajaran jarak jauh ini. Pembelajaran jarak jauh berbasis mobile e-learning di MI Hidayatul Mubtadiin ini bertujuan agar siswa tetap dapat melangsungkan pembelajaran selama masa pandemi yang tidak tahu kapan akan berakhir. Namun dikarenakan model pembelajaran jarak jauh yang belum pernah dilaksanakan sebelumnya ini pastinya tak luput dari hambatan dan kekurangan, seperti halnya banyak guru yang belum mahir mengajar dengan menggunakan teknologi internet, siswa yang cenderung lebih mudah paham dengan model pembelajaran tatap muka, serta peran orang tua dalam mendampingi putra/putrinya.

\section{METODE}

Penelitian ini termasuk dalam jenis penelitian kualitatif deskriptif. Peneliti memperoleh temuan-temuannya melalui pengumpulan data yang benar-benar terjadi di lapangan dengan menempatkan peneliti sebagai instrumen kunci yang bertujuan untuk mengungkapkan indikasi secara holistik-kontekstual. Subjek dalam penelitian ini adalah guru dan siswa kelas I, IV dan VI MI Hidayatul Mubtadiin Sumbergempol Tulungagung, serta orang tua siswa dengan keseluruhan subjek berjumlah 235 orang. Pemilihan kelas I bertujuan untuk mengetahui pelaksanaan serta faktor penghambat dari kelas rendah yang dipandang sangat membutuhkan banyak bimbingan guru dalam belajar, pemilihan kelas IV bertujuan untuk mengetahui pelaksanaan serta faktor penghambat dari siswa yang baru saja beranjak ke kelas tinggi sehingga memiliki cara berpikir yang masih berkembang dari kelas rendah, sedangkan pemilihan kelas VI bertujuan untuk mengetahui pelaksanaan serta faktor penghambat dari kelas tinggi yang akan menghadapi ujian akhir kelulusan. Pengumpulan data dilakukan mulai tanggal 05 Februari 2021 hingga tanggal 04 Maret 2021. Teknik pengumpulan data dalam penelitian ini adalah observasi, wawancara, questioner menggunakan survei online google form yang didistribusikan dalam bentuk tautan melalui grup whatsapp masing-masing kelas, dan dokumentasi. Teknis analisis data yang digunakan dalam penelitian ini adalah reduksi data, paparan data, dan penarikan kesimpulan/verifikasi. Pengesahan keabsahan data dalam penelitian ini menggunakan teknik trianggulasi. 


\section{HASIL DAN PEMBAHASAN}

\section{Perencanaan dalam Pembelajaran Jarak Jauh}

Sebuah kegiatan tentunya selalu memiliki perencanaan tertentu sebelum terlaksananya kegiatan tersebut, tak terkecuali dengan kegiatan pembelajaran. Perencanaan program pembelajaran perlu dilakukan agar pelaksanaan pembelajaran tersebut berjalan dengan baik sehingga dapat mencapai tujuan dari pembelajaran. Rencana pembelajaran dapat berupa tindakan-tindakan yang dilakukan dengan maksud memperlancar pelaksanaan pembelajaran itu sendiri, rencana ini juga dapat memudahkan guru dalam proses belajar mengajar. Perencanaan pembelajaran jarak jauh atau pembelajaran daring bereda dengan pembelajaran biasa karena media dan alat belajarnya yang berbeda pula. Pembelajaran jarak jauh memanfaatkan smartphone yang diharuskan terhubung dengan internet untuk melaksanakan pembelajaran dengan posisi peserta didik dan guru berjauhan. Perencanaan sistem pembelajaran daring menurut Albert mengacu pada tiga prinsip yang harus dipenuhi yaitu sistem pembelajaran harus sederhana sehingga mudah untuk dipelajari, sistem pembelajaran bersifat personal sehingga penggunaan sistem tidak saling bergantung dan sistem sebagai hasil perancangan sistem yang dikembangkan harus cepat dalam proses pencarian materi atau menjawab soal. ${ }^{8}$ Tiga prinsip tersebut diterapkan dalam pembelajaran jarak jauh yang dilaksanakan oleh MI Hidayatul Mubtadiin, Wates Sumbergempol Tulungagung yang dapat dilihat berdasarkan hasil penelitian yang dilakukan peneliti sebagai berikut:

1. Sistem pembelajaran harus sederhana sehingga mudah untuk dipelajari, prinsip ini berdasarkan hasil wawancara dengan guru diterapkan dalam pembuatan Rencana Pelaksanaan Pembelajaran (RPP) daring yang kegiatan pembelajarannya bersifat fleksibel dengan menyesuaikan keadaan peserta didik di rumah. Penyampaian materi dan tugas dibuat lebih sederhana dari biasanya, tidak memberatkan peserta didik dengan menggunakan media yang ada di sekitar lingkungan rumah serta tetap memperhatikan kenyamanan peserta didik. Berdasarkan dokumen RPP daring yang guru berikan pada peneliti terlihat bahwasanya proses penyusunan RPP tetap terdiri dari kegiatan menetapkan Kompetensi Inti (KI) dan Kompetensi Dasar (KD), mengembangkan indikator pembelajaran, pemilihan bahan ajar, strategi, dan media hingga pengembangan instrument penilaian sebagai program evaluasi hasil belajar peserta didik tetap dilakukan secara sistematis hanya saja pada bagian kegiatan inti pembelajaran dilakukan dengan sangat sederhana seperti pemberian tugas mengerjakan soal dan pemberian materi dengan mengirimkan video pembelajaran saja dikarenakan kondisi guru dan peserta didik yang tidak dapat melaksanakan pembelajaran secara tatap muka dan hanya menggunakan

${ }^{8}$ Albert Efendi Pohan, Konsep Pembelajaran Daring, (Purwodadi: CV Sarnu Untung, 2020). 
smartphone sebagai alat perantara sehingga tidak memungkinkan untuk melakukan kegiatan inti pembelajaran dengan berbagai kegiatan yang menjabar dan terperinci. Kegiatan yang disederhanakan ini berdampak pada metode pembelajaran yang digunakan tidak dapat bervariasi dengan Langkah kegiatan yang diperpendek dan penggunaan media serta sumber belajar yang hanya bisa diakses secara online.

2. Sistem pembelajaran bersifat personal sehingga penggunaan sistem tidak saling bergantung, prinsip ini berdasarkan hasil wawancara dengan peserta didik dan pengisian questioner menunjukkan bahwa semua peserta didik memiliki smartphone baik milik sendiri maupun milik orang tua atau saudara sebagai alat dalam mengikuti pembelajaran jarak jauh serta dapat mengoperasikannya dengan baik. Demi kelancaran pelaksanaan pembelajaran, peserta didik yang belum bisa mengoperasikan smartphone didampingi oleh orang dewasa yang dapat mengoperasikannya selama pembelajaran berlangsung. Pelaksanaan pembelajaran jarak jauh juga didukung dengan adanya subsidi paket internet dari pemerintah yang diberikan secara langsung kepada peserta didik yang berupa SIM Card maupun kuota internet yang secara langsung diterima pada nomor telepon yang telah didaftarkan pihak sekolah.

3. Sistem sebagai hasil perancangan sistem yang dikembangkan harus cepat dalam proses pencarian materi atau menjawab soal, prinsip ini berdasarkan hasil wawancara dengan guru kelas diterapkan dengan membuat grup whatsapp sebagai sarana utama untuk melaksanakan pembelajaran selama pandemi. Whatsapp merupakan aplikasi berkirim pesan yang Sebagian besar masyarakat gunakan untuk melakukan komunikasi sehari-hari dengan keluarga, teman maupun rekan kerja dengan vitur yang selalu berkembang mulai dari pesan teks, panggilan suara hingga panggilan video. Penggunaan aplikasi whatsapp juga berkembang dalam penggunaannya yaitu mulai hanya untuk sarana komunikasi merambah ke bidang bisnis dan pada masa pandemi ini dimanfaatkan dalam bidang pendidikan. Whatsapp dimanfaatkan sebagai sarana utama untuk melaksanakan pembelajaran pada grup kelas yang berisikan seluruh anggota kelas dan guru sehingga materi, tugas dan media pembelajaran yang guru kirimkan dapat diakses secara langsung oleh peserta didik dengan cepat bahkan untuk mengerjakan soal atau ulangan harian peserta didik tidak perlu mengambil lembar soal ke sekolah dan mengerjakannya secara manual melainkan hanya men-klik link google form yang guru kirimkan di grup whatsapp, peserta didik dapat langsung mengisi data diri dan mengerjakan soal yang telah tertera di smartphone masing-masing. Hasil pekerjaan peserta didik dapat langsung terkirim pada guru melalui tombol submit dan secara otomatis muncul nilai yang peserta didik dapatkan serta muncul jawaban pembenaran pada soal yang dijawab salah oleh peserta didik. 
Rencana pelaksanaan pembelajaran jarak jauh di MI Hidayatul Mubtadiin, Wates Sumbergempol Tulungagung selain menerapkan tiga prinsip yang telah dipaparkan juga melakukan persiapan dengan diadakannya sosialisasi dengan orangtua peserta didik mengenai pelaksanaan pembelajaran jarak jauh menggunakan smartphone sebagai media dan alat pembelajarannya. Berdasarkan hasil wawancara dengan guru kelas menyatakan bahwa sosialisasi dilakukan dengan sistem otonomi wali kelas dimana sosialisasi dilakukan sesuai kesepakatan orang tua dengan wali kelas masing-masing, tidak dilakukan secara serempak dengan sistem orang tua datang ke sekolah dikarenakan mematuhi peraturan physical distancing atau menghindari kerumunan untuk mencegah penyebaran virus covid-19 yang tengah berlaku. Sosialisasi pada beberapa kelas dilakukan melalui pengumuman pada grup Whatsapp bahwasanya pembelajaran tatap muka ditiadakan diganti dengan pembelajaran daring yang dilaksanakan pada grup yang telah dibuat oleh wali kelas tersebut dengan tata cara proses pembelajaran dijelaskan seiring berlangsungnya pembelajaran.

Beberapa kelas lain melakukan sosialisasi dengan menghubungi satu persatu orang tua peserta didik dan memberikan penjelasan secara terperinci mengenai prosedur pembelajaran daring yang akan dilakukan selama masa pandemi. Salah satu kelas memanfaatkan aplikasi zoom meeting untuk melakukan sosialisasi agar orang tua berkesempatan menanyakan mekanisme pembelajaran daring yang belum dimengerti yang secara langsung akan dijelaskan oleh wali kelas yang mengadakan panggilan video tersebut. Sosialisasi ini bertujuan agar orang tua dapat memahami mekanisme pembelajaran daring dan dapat mendampingi putra/putri mereka selama pembelajaran berlangsung demi kelancaran tersampaikannya materi pada seluruh peserta didik yang ada di rumah masing-masing.

\section{Pelaksanaan dalam Pembelajaran Jarak Jauh}

Pelaksanaan pembelajaran merupakan kegiatan inti dalam proses belajar mengajar, pada bagian ini guru berperan dalam memberikan materi, informasi dan pengetahuan penting lainnya yang dibutuhkan oleh peserta didik. ${ }^{9}$ Pemberian materi dilakukan guru dengan berbagai metode dan strategi agar mudah diterima dan dipahami oleh peserta didik namun dalam kondisi pandemi saat ini guru tidak dapat menyampaikan materi dan informasi secara langsung dan gamblang seperti saat pembelajaran tatap muka dimana guru dan peserta didik berhadapan di ruang kelas, pemberian materi dalam pembelajaran jarak jauh memerlukan pemanfaatan teknologi informasi dan komunikasi dalam setiap kegiatannya karena terhalang jarak antara guru dengan peserta didiknya. Beberapa teknologi yang dimanfaatkan guru sebagai media pembelajaran adalah aplikasi zoom meeting, google classroom, whatsapp dan

${ }^{9}$ Ahmad Susanto, Teori Belajar Dan Pembelajaran Di Sekolah Dasar (Jakarta: Kencana, 2013). 
youtube. ${ }^{10}$ Pemanfaatan beberapa aplikasi tersebut sangat membatu guru dalam kegiatan belajar mengajar sehingga peserta didik dapat terus menerima pengetahuan meski berada di rumah masing-masing.

Pembelajaran jarak jauh di MI Hidayatul Mubtadiin, Wates Sumbergempol Tulungagung berdasarkan wawancara dengan guru dan peserta didik serta observasi peneliti menunjukkan bahwa pembelajaran memanfaatkan aplikasi-aplikasi yang telas ada dan digunakan oleh masyarakat umum seperti whatsapp, zoom meeting, google form, dan youtube bukan berupa aplikasi yang dikembangkan untuk pembelajaran khusus dengan pertimbangan memudahkan orang tua maupun peserta didik dalam mengoperasikan aplikasi tersebut karena beberapa aplikasi yang digunakan Sebagian besar telah terinstal dalam smartphone peserta didik dan telah terbiasa mengoperasikannya sehingga guru atau pihak sekolah tidak perlu lagi untuk mengajari mekanisme pengoperasian aplikasi yang digunakan selama pembelajaran. Beberapa aplikasi tersebut dimanfaatkan dengan ketentuan-ketentuan yang berbeda, whatsapp sebagai aplikasi utama dimanfaatkan sebagai media dan tempat untuk proses pembelajaran secara keseluruhan mulai dari pembukaan, pemberian materi atau tugas, hingga penutupan dan pengumpulan hasil belajar atau dokumentasi selama peserta didik belajar.

Whatsapp juga berfungsi sebagai alat komunikasi antar guru dengan peserta didik, guru dengan orang tua bahkan peserta didik dengan peserta didik lainnya. Google form dimanfaatkan untuk media mengerjakan soal, ulangan harian ataupun kuiz setelah pembelajaran usai karena pemanfaatan google form ini sangat memudahkan guru dalam menilai hasil belajar peserta didiknya, hasil pekerjaan peserta didik dapat langsung terkirim pada guru melalui tombol submit dan secara otomatis muncul nilai yang peserta didik dapatkan serta muncul jawaban pembenaran pada soal yang dijawab salah oleh peserta didik. Dengan hal ini peserta didik dapat mengoreksi kesalahan mereka dan membenahinya pada ulangan selanjutnya. Aplikasi youtube dimanfaatkan untuk memberikan penjelasan atau prosedur-prosedur kegiatan praktik berupa video dan zoom meeting digunakan saat mata pelajaran dengan materi yang sulit yang memerlukan penjelasan langsung dari guru sehingga memerlukan aplikasi yang dapat menampilkan guru dengan keseluruhan peserta didik dalam kelas.

Pelaksanaan pembelajaran menurut standar proses dalam kurikulum 2013 meliputi kegiatan pendahuluan, kegiatan inti yang mencakup kegiatan mengamati, menanya, mengumpulkan informasi dan mengomunikasikan hasil belajar serta kegiatan penutup. ${ }^{11}$ Beberapa kegiatan tersebut tidak lagi diwajibkan dalam kurikulum darurat pandemi covid-19,

${ }^{10}$ Meda Yuliani Dkk, Pembelajaran Daring Untuk Pendidikan: Teori Dan Penerapan (Medan: Yayasan Kita Menulis, 2020).

${ }^{11}$ Latifah Hanum, Perencanaan Pembelajaran (Banda Aceh: Syiah Kuala University Press, 2017). 
terbitnya ketentuan pembelajaran daring yang diatur dalam Peraturan Menteri Pendidikan dan Kebudayaan Republik Indonesia melalui Surat Edaran Nomor 4 Tahun 2020 tentang batasanbatasan dalam pelaksanaan pembelajaran daring. Batasan-batasan tersebut meliputi: peserta didik tidak dibebani tuntutan menuntaskan seluruh capaian kurikulum untuk kenaikan kelas, pembelajaran dilaksanakan untuk memberikan pengalaman belajar yang bermakna bagi peserta didik, difokuskan pada pendidikan kecakapan hidup, tugas dan kegiatan disesuaikan dengan minat dan kondisi peserta didik serta mempertimbangkan kesenjangan akses dan fasilitas belajar di rumah, bukti atau produk kegiatan belajar dari rumah diberi umpan balik yang bersifat kualitatif dari guru tanpa harus berupa skor/nilai dalam bentuk angka. ${ }^{12}$

Dengan adanya Batasan-batasan ini pelaksanaan pembelajaran menjadi lebih sederhana setidaknya harus mencakup tiga hal sebagaimana teori yang dikemukakan oleh Ahmad Susanto yaitu: Membuka pelajaran, umumnya merupakan awal dari kegiatan belajar mengajar dengan kegiatan menyampaikan motivasi pada peserta didik agar tumbuh semangat belajar, menarik perhatian agar memperhatikan guru serta memberikan pengertian pada peserta didik mengenai tujuan pembelajaran dan kontekstualisasi materi dengan kehidupan sehari-hari peserta didik sesuai dengan jenjang pendidikan yang mereka tempuh. Menyampaikan materi, merupakan kegiatan utama dalam proses belajar mengajar yang bertujuan dalam penanaman dan pengembangan potensi siswa baik dari aspek kognitif, afektif dan psikomotornya. Menutup pelajaran, bertujuan untuk mengakhiri proses kegiatan belajar mengajar yang dipandu oleh guru, dalam kegiatan menutup pelajaran ini guru perlu memberikan gambaran menyeluruh tentang materi yang telah dipelajari peserta didik dalam satu pertemuan dan melihat tingkat pemahaman peserta didik serta tingkat keberhasilan guru dalam kegiatan pembelajaran yang telah dilakukan. ${ }^{13}$

Berdasarkan hasil observasi pelaksanaan pembelajaran jarak jauh dengan media aplikasi whatsapp di MI Hidayatul Mubtadiin, Wates Sumbergempol Tulungagung telah memenuhi tiga kegiatan yang mencakup membuka pelajaran, menyampaikan materi dan menutup pelajaran yang diuraikan sebagai berikut:

1. Kegiatan membuka pelajaran dilakukan dengan salam dan mengarahkan peserta didik untuk berdo'a sebelum memulai aktivitas belajar disertai dengan membaca beberapa surah pendek dan asmaul husna. Pembiasaan karakter agama di sekolah dengan melaksanakan sholat dhuha tetap dilakukan walaupun dalam posisi peserta didik di rumah masingmasing, absen sholat dhuha dan sholat lima waktu tetap berjalan seperti yang selama ini

\footnotetext{
${ }^{12}$ Kemendikbud, "Surat Edaran Mendikbud No 4 Tahun 2020 Tentang Pelaksanaan Kebijakan Pendidikan Dalam Masa Darurat Penyebaran Virus Corona," Direktorat Guru Dan Tenaga Kependidikan Pendidikan Menengah dan Pendidikan Khusus, 2020.

${ }^{13}$ Susanto, Teori Belajar Dan Pembelajaran Di Sekolah Dasar.
} 
menjadi ciri khusus dari pembiasaan karakter agama di MI Hidayatul Mubtadiin. Motivasi belajar dari guru juga disampaikan dengan kalimat-kalimat yang membangkitkan minat belajar peserta didik hingga mengingatkan bahwa ujian kelulusan semakin dekat agar siswa kelas VI tetap semangat belajar meski dari rumah.

2. Kegiatan menyampaikan materi dituliskan secara terperinci permata pelajaran atau tema mulai dari bab, sub bab hingga nomor halaman pada buku siswa dengan penjelasan materi menggunakan berbagai media yang sesuai dengan materi yang diajarkan dalam pertemuan tersebut. Intruksi kegiatan belajar disampaikan guru menggunakan rekaman suara atau voice note yang guru kirimkan untuk memperjelas materi yang siswa baca pada buku paket atau buku tema masing-masing. Penggunaan media visual berupa gambar juga digunakan dalam menyampaikan materi yang cukup sederhana seperti foto kegiatan tertentu atau gambar-gambar yang berkaitan dengan materi yang akan dipelajari. Media audio visual dimanfaatkan untuk menjelaskan materi yang tergolong sulit, video pembelajaran yang menjelaskan materi sulit tersebut dapat diakses dengan memberikan link yang terhubung ke youtube sehingga siswa dapat melihatnya tanpa memenuhi kapasitas internal smartphone mereka dengan berbagai video yang guru kirimkan. Peserta didik mengakses semua materi secara online dan jika belum dapat memahami materi yang dipelajari pada pertemuan tersebut peserta didik dapat bertanya secara pribadi pada guru kelas masing-masing sehinga guru dapat memberikan alternatif lain agar peserta didik dapat dengan mudah memahami informasi salah satu usahanya dengan mengadakan pertemuan pada zoom meeting. Kegiatan belajar hanya berupa memberikan materi secara garis besar dan sisanya siswa hanya diminta membaca pada buku tema maupun buku paket yang dimiliki siswa di rumah. Pemberian tugas tertulis pun tidak diberikan setiap harinya agar siswa tidak merasa terbebani dan merasa cepat bosan untuk belajar di rumah. Pemberian tugas lebih ditekankan pada praktik-praktik yang memungkinkan dilakukan di rumah dengan mempertimbangkan kemampuan siswa dan orang tua yang mendampingi belajar seperti eksperimen sederhana dengan memanfaatkan bahan/barang yang ada dirumah, membuat kerajinan sederhana, melakukan olahraga sederhana dan kegiatan menjaga kebersihan diri dan lingkungan.

3. Kegiatan menutup pelajaran dilakukan setelah seluruh peserta didik mengirimkan tugas dan dokumentasi kegiatan belajar dirumah pada guru. Kegiatan mengirimkan tugas dan dokumentasi kegiatan belajar ini sekaligus menjadi absen kehadiran peserta didik dalam kegiatan pembelajaran pada pertemuan tersebut sehingga peserta didik yang tidak mengirimkan dokumentasi apapun dianggap tidak hadir. Menutup pelajaran dilakukan guru dengan mengucapkan terimakasih kepada peserta didik yang telah mengikuti 
kegiatan pembelajaran jarak jauh dan memenuhi tugas yang diberikan guru dengan baik, selain menjadi penutup ucapan terimakasih ini juga berfungsi sebagai apresiasi dan umpan balik dari guru untuk peserta didik yang dengan senang hati tetap belajar dan mencari pengetahuan untuk menghilangkan kebodohan dalam diri mereka.

Pembelajaran jarak jauh yang identik dengan kegiatan pembelajaran yang disederhanakan ini juga identik dengan dua macam komunikasi yang berlangsung kegiatan selama pembelajarannya. Dua macam komunikasi dalam pembelajaran jarak jauh ini disebut dengan komunikasi synchronous dan komunikasi asynchronous. Menurut Simoson, Smaldino dan Zvacek definisi dari komunikasi synchronous adalah komunikasi yang instruksinya dapat dikirimkan ke tempat yang berbeda pada saat yang sama ketika sistem telekomunikasi digunakan sedangkan komunikasi asynchronous adalah komunikasi yang memungkinkan siswa belajar pada waktu yang berbeda dan di tempat-tempat yang berbeda. ${ }^{14}$ Berdasarkan definisi tersebut, peneliti menemukan dua macam komunikasi sekaligus digunakan dalam pembelajaran jarak jauh di MI Hidayatul Mubtadiin, hal ini berdasarkan hasil observasi yang peneliti lakukan menunjukkan bahwa komunikasi synchronous terjadi saat pembelajaran dilaksanakan menggunakan aplikasi zoom dan whatsapp videocall sedangkan komunikasi asynchronous terjadi saat pembelajaran dilaksanakan menggunakan whatsapp chat dan google form. Namun demi melatih sikap disiplin dan tanggung jawab dalam diri siswa, guru tetap menentukan batas waktu pengumpulan tugas selama komunikasi berlangsung secara asynchronous.

\section{Faktor Penghambat dalam Pembelajaran Jarak Jauh}

Melaksanakan sebuah kegiatan tidak selalu berjalan seperti apa yang direncanakan, ada kalanya kegiatan mengalami beberapa kendala yang menghambat berjalannya kegiatan tersebut. Tidak terkecuali dalam kegiatan pembelajaran apalagi pembelajaran jarak jauh yang belum dilakukan sebelumnya, banyak kendala yang guru, peserta didik ataupun orang tua alami selama mendampingi pembelajaran di rumah. Hambatan-hambatan muncul dari berbagai faktor baik dari faktor luar maupun dari dalam diri individu atau kelompok. Menurut Slameto faktor penghambat dalam pembelajaran dibagi menjadi dua yaitu faktor internal dan faktor eksternal. Faktor internal mencakup faktor fisiologis/fisik yaitu faktor yang berhubungan dengan kondisi fisik individu dan faktor psikologis/psikis yaitu meliputi intelegensi, perhatian siswa, minat, bakat, motivasi, dan kematangan. Faktor eksternal mencakup faktor keluarga (meliputi cara orang tua mendidik anak dan relasi antara keluarga), faktor sekolah (meliputi guru, administrasi, kurikulum, relasi guru dengan peserta didik, alat

${ }^{14}$ Michael Simoson $\mathrm{dkk}$, Teaching and Learning at a Distance, 6th ed. (North Carolina: Information Age Publishing, 2015). 
pelajaran dan teman sekitar), dan faktor masyarakat yaitu kondisi lingkungan masyarakat tempat tinggal peserta didik yang mempengaruhi aktivitas belajar. ${ }^{15}$

Berdasarkan hasil wawancara dengan guru, peserta didik dan orang tua MI Hidayatul Mubtadiin serta pengisian questioner menyatakan bahwa ada beberapa faktor penghambat selama melaksanakan pembelajaran jarak jauh di masa pandemi yang juga meliputi faktor internal dan faktor eksternal yang diuraikan sebagai berikut:

1. Faktor fisiologis/fisik yaitu kondisi fisik peserta didik yang berjauhan dengan guru sangatlah berpengaruh kepada pemahaman peserta didik. Cara berpikir anak usia sekolah dasar berada pada periode operasional konkret dimana anak hanya dapat memahami sesuatu yang nyata dihadapannya sehingga siswa masih sangat membutuhkan bimibingan guru untuk mengembangkan cara berpikirnya. Kondisi pembelajaran jarak jauh yang menggunakan perantara dalam penyampaian materi dan informasi sangat menghambat pemahaman peserta didik karena berupa pembelajaran yang tidak dapat dikonkretkan atau virtual.

2. Faktor psikologis/psikis yaitu kurangnya pemahaman peserta didik yang berujung pada rasa bosan dan malas dalam belajar yang dapat mengalihkan perhatian peserta didik pada bermain game atau menonton video di youtube atau aplikasi lain yang tidak berkaitan dengan materi pelajaran sehingga tujuan pembelajaran tidak tercapai secara maksimal.

3. Faktor keluarga yaitu keadaan orang tua yang sibuk bekerja sehingga tidak selalu bisa mendampingi proses belajar putra/putrinya dan mengakibatkan tidak kondusifnya suasana belajar di rumah. Selain itu ketidak pahaman orang tua mengenai materi pelajaran anak sering membuat mereka bingung bagaimana cara menjelaskan kepada anak mereka yang belum paham dari penjelasan guru, hal ini membutuhkan energi tambahan dari orang tua untuk ikut mempelajari materi dan mencarikan sumber referensi tambahan bagi anak mereka.

4. Faktor sekolah yaitu metode pembelajaran yang kurang bervariasi dari guru karena kondisi fisik yang berjauhan sehingga guru hanya bisa menyampaikan garis besar dari materi yang harus dipelajari peserta didik yang memicu banyaknya pemberian tugas. Guru juga kesulitan dalam memberikan penilaian proses belajar peserta didik karena tidak dapat memantau secara langsung aktivitas belajar yang dilakukan oleh setiap peserta didik.

5. Faktor masyarakat yaitu berlakunya Pembatasan Sosial Berskala Besar (PSBB) dan physical distancing di masa pandemi covid-19 berdampak pada menurunnya penghasilan masyarakat termasuk wali murid MI Hidayatul Mubtadiin. Menurunnya perekonomian ini membuat orang tua merasa keberatan karena harus membayar SPP secara penuh dan

${ }^{15}$ Slameto, Belajar Dan Faktor-Faktor Yang Mempengaruhinya (Jakarta: Rineka Cipta, 2006). 
masih membelikan kuota internet sebagai fasilitas belajar anak dirumah sehingga terjadi pembengkakan pengeluaran dana. Selain itu kendala terjadi pada penggunaan alat yaitu smartphone sebagai perantara dan penunjang pembelajaran jarak jauh yaitu kapasitas RAM yang tidak memadai sehingga peserta didik tidak dapat mengakses media pembelajaran yang guru kirimkan. Beberapa peserta didik bahkan guru banyak yang mengeluhkan jaringan internet yang tidak stabil sehingga sering terjadi loading atau jaringan lemot dalam mengakses pembelajaran dari guru maupun mengirimkan hasil belajar.

\section{KESIMPULAN}

Pembelajaran jarak jauh di MI Hidayatul Mubtadiin, Wates Sumbergempol Tulungagung direncanakan dengan membuat Rencana Pelaksanaan Pembelajaran (RPP) daring yang kegiatan pembelajarannya disederhanakan menyesuaikan kondisi dan kemampuan peserta didik di rumah dan melakukan sosialisasi yang bersifat otonomi kelas untuk menjelaskan mekanisme pelaksanaan pembelajaran jarak jauh. Pelaksanaan pembelajaran jarak jauh dilaksanakan dengan media aplikasi whatsapp sebagai aplikasi utama dan didukung dengan aplikasi zoom meeting, google form, serta youtube. Kegiatan belajar hanya berupa memberikan materi secara garis besar dan sisanya siswa hanya diminta membaca pada buku dan mengerjakan soal. Pemberian tugas lebih ditekankan pada praktikpraktik yang memungkinkan dilakukan di rumah dengan mempertimbangkan kemampuan siswa dan orang tua yang mendampingi belajar. Faktor penghambat pembelajaran berupa kurangnya pemahaman siswa, kurangnya motivasi belajar siswa di rumah, keadaan orang tua yang tidak bisa selalu mendampingi belajar anak, kapasitas dari alat komunikasi yang tidak memadai, penurunan pendapatan ekonomi orang tua di masa pandemi, dan jaringan internet yang tidak stabil.

\section{SARAN}

Hasil penelitian ini diharapkan dapat dijadikan sebagai informasi agar dapat meningkatkan mutu dan merancang pembelajaran yang relevan dengan perkembangan ilmu pengetahuan. Diharapkan pihak sekolah agar tetap menjaga komunikasi yang baik dengan orang tua siswa untuk menjalin kerjasama dalam perkembangan belajar siswa, karena pembelajaran tidak hanya bergantung kepada guru namun juga dibutuhkan tindak lanjut di rumah dengan orang tua sebagai pendidik utamanya. 


\section{DAFTAR PUSTAKA}

Chick, Robert Connor, Guy Travis Clifton, Kaitlin M. Peace, Brandon W. Propper, Diane F. Hale, Adnan A. Alseidi, and Timothy J. Vreeland. "Using Technology to Maintain the Education of Residents During the COVID-19 Pandemic." Journal of Surgical Education, 2020. https://doi.org/10.1016/j.jsurg.2020.03.018.

Discenza, Richard dkk. The Design and Management of Effective Distance Learning Programs. London: IRM Press, 2002.

Hanum, Latifah. Perencanaan Pembelajaran. Banda Aceh: Syiah Kuala University Press, 2017.

Imanuddin, Muhammad. Membuat Kelas Online Berbasis Android Dengan Google Classroom. Yogyakarta: Garudhawaca, 2018.

Kemendikbud. "Surat Edaran Mendikbud No 4 Tahun 2020 Tentang Pelaksanaan Kebijakan Pendidikan Dalam Masa Darurat Penyebaran Virus Corona." Direktorat Guru Dan Tenaga Kependidikan Pendidikan Menengah dan Pendidikan Khusus, 2020.

Pohan, Albert Efendi. Konsep Pembelajaran Daring. Purwodadi: CV Sarnu Untung, 2020.

Setiawan, Yohan Adi. Belajar Android Menyenangkan. Surabaya: Pustaka Media Guru, 2017.

Simanihuruk, Lidia dkk. E-Learning: Implementasi, Strategi, Dan Inovasinya. Medan: Yayasan Kita Menulis, 2019.

Simoson, Michael dkk. Teaching and Learning at a Distance. 6th ed. North Carolina: Information Age Publishing, 2015.

Slameto. Belajar Dan Faktor-Faktor Yang Mempengaruhinya. Jakarta: Rineka Cipta, 2006.

Susanto, Ahmad. Teori Belajar Dan Pembelajaran Di Sekolah Dasar. Jakarta: Kencana, 2013.

Rogers, Patricia dkk. Encyclopedia of Distance Learning. 2nd ed. New York: Information Science Reference, 2009.

Tanduklangi, Amri dan Carlina Amri. Manajemen Sumber Daya Pembelajaran Bahasa Berbantuan Komputer. Yogyakarta: Deepublish, 2019.

Yuliani, Meda dkk. Pembelajaran Daring Untuk Pendidikan: Teori Dan Penerapan. Medan: Yayasan Kita Menulis, 2020. 